\title{
A Predictive Study of Student Satisfaction in Online Education Programs
}
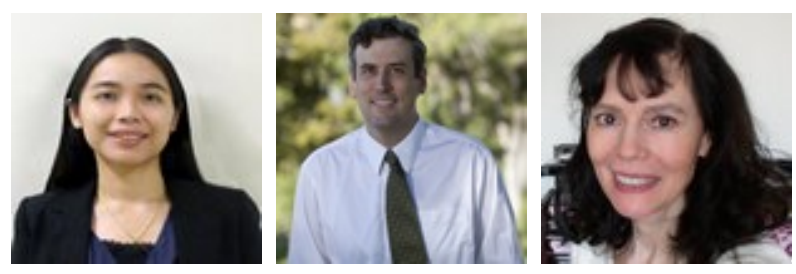

Yu-Chun Kuo ${ }^{1}$, Andrew E. Walker (not shown)2, Brian R. Belland², and Kerstin E. E. Schroder ${ }^{3}$ ${ }^{1}$ Jackson State University, USA, ${ }^{2}$ Utah State University, USA, ${ }^{3}$ University of Alabama at Birmingham, USA

\section{Abstract}

This paper is intended to investigate the degree to which interaction and other predictors contribute to student satisfaction in online learning settings. This was a preliminary study towards a dissertation work which involved the establishment of interaction and satisfaction scales through a content validity survey. Regression analysis was performed to determine the contribution of predictor variables to student satisfaction. The effects of student background variables on predictors were explored. The results showed that learner-instructor interaction, learner-content interaction, and Internet self-efficacy were good predictors of student satisfaction while interactions among students and self-regulated learning did not contribute to student satisfaction. Learner-content interaction explained the largest unique variance in student satisfaction. Additionally, gender, class level, and time spent online per week seemed to have influence on learner-learner interaction, Internet self-efficacy, and self-regulation.

Keywords: Interaction; satisfaction; self-regulation; Internet-self efficacy; online learning; regression 


\section{Introduction}

Academic leaders in the United States indicated that online learning is critical to the long-term growth of their institutions, reporting that the increase in demand for online courses or programs is greater than that for face-to-face courses. Nearly one third of higher education students enrolled in at least one online course (Allen \& Seaman, 2008; Allen \& Seaman, 2010). According to previous studies, online learning does not differ considerably from traditional face-to-face classroom learning in terms of learning outcomes (Allen \& Seaman, 2010; Allen, Bourhis, Burrell \& Mabry, 2002; Biner, Bink, Huffman \& Dean, 1997; Brown \& Liedholm, 2002; J ohnson, 2000). Student satisfaction in online learning remains undiminished when compared to face-to-face instruction (Allen \& Seaman, 2010).

Student satisfaction is an important indicator of the quality of learning experiences (Moore \& Kearsley, 1996; Yukselturk \& Yildirim, 2008). It is worthwhile to investigate student satisfaction in online settings because new technologies have altered the way that students interact with instructors and classmates (Kaminski, Switzer, \& Gloeckner, 2009). The quality of interaction in online settings may depend to a large extent on the technology tools utilized during learning (Parsad \& Lewis, 2008). Lack of confidence in using information and communication technology (ICT) may decrease students' satisfaction during online instruction and in turn lower their performance. As opposed to face-to-face instruction, the nature of online learning demands greater responsibility on the part of learners (Moore \& Kearsley, 1996). Online learners who are unable to regulate learning efficiently are unlikely to be satisfied (Artino, 2007; Puzziferro, 2008) This study investigated factors (i.e., Interaction, Internet self-efficacy, self-regulation) associated with student satisfaction in fully online learning settings.

\section{Literature Review}

\section{Student Satisfaction}

Evaluation is important in distance education and it consists of different dimensions in alignment with the goals of a course or program (Olmstead, 2007). Course grades are often used as an indicator of student achievement in online instruction (Barnard, Paton, \& Lan, 2008; Reinhart \& Schneider, 2001; Noel-Levitz, 2011). But affective factors can be as important as cognitive factors in explaining and predicting student learning in online settings (Biner et al., 1997). Among the attitudinal constructs, student satisfaction, referring to student perceptions of learning experiences and perceived value of a course, may be particularly worthy of investigation. Student satisfaction is related to several outcome variables such as persistence (Allen \& Seaman, 2008), retention (Debourgh, 1999; Koseke, \& Koseke, 1991), course quality (Moore \& Kearsley, 1996), and student success (Keller, 1983; Pike, 1993; Noel-Levitz, 2011). High 
satisfaction leads to lower attrition rates, higher persistence in learning, and higher motivation in pursuing additional online courses (Allen \& Seaman, 2008; Biner, Welsh, Barone, Summers, \& Dean, 1997; Keller, 1987; Koseke, \& Koseke, 1991). Higher education institutions consider student satisfaction as one of the major elements in determining the quality of online programs in today's markets (Yukselturk \& Yildirim, 2008). Online learner perspectives provide valuable information on the areas that matter to students and help institutions gain a better understanding of their strengths and challenges in provision of online programs (Noel-Levitz, 2011). With data on student satisfaction, course designers, educators, and administrators can identify areas where improvement is needed (Reinhart \& Schneider, 2001).

\section{Predictors of Student Satisfaction}

Previous studies have determined factors that influence student satisfaction in distance learning environments (Artino, 2007; Bolliger \& Martindale, 2004; Reinhart \& Schneider, 2001; Sahin, 2007). The framework of this study was proposed based on the interaction model developed by Moore (1989) with the addition of potential variables including Internet self-efficacy and self-regulated learning.

\section{Interaction.}

Interaction has been deemed one of the most important components in distance education due to the isolation of instructors and learners (Moore \& Kearsley, 1996). Moore (1989) proposed an interaction framework including learner-learner interaction, learner-instructor interaction, and learner-content interaction.

Learner-learner interaction refers to two-way reciprocal communication between or among learners who exchange information, knowledge, thoughts, or ideas regarding course content, with or without the presence of an instructor (Moore \& Kearsley, 1996). Learner-instructor interaction consists of two-way communication between the instructor of a course and learners. Learner-content interaction is a process of individual learners elaborating and reflecting on the subject matter or the course content. In contrast with learner-instructor and learner-learner interaction, only one person - the learner - is directly involved in learner-content interaction (Moore \& Kearsley, 1996).

Other authors have used Moore's interaction model as a basis for new interaction models. Hillman, Willis, and Gunawardena (1994) proposed learner-interface interaction to recognize the importance of technology interfaces in interaction with content, instructors, or learners. Anderson and Garrison (1995) expanded Moore's interaction model by adding three new types of interaction: instructor-instructor, instructor-content, and content-content interaction.

Previous research has indicated the positive influence of interaction on student satisfaction in distance education (Bray et al., 2008; Burnett, 2001; Moore \& Kearsley, 
1996; Northrup, Lee \& Burgess, 2002; Thurmond \& Wambach, 2004). Of the three types of interaction, learner-learner interaction and learner-instructor interaction were investigated more often than learner-content interaction. Learner-learner interaction and learner-instructor interaction seem to be more related to and predictive of student satisfaction than learner-content interaction in most studies of online learning (Bolliger \& Martindale, 2004; Jung, Choi, Lim \& Leem, 2002; Rodriguez Robles, 2006; Thurmond, 2003). Battalio (2007) concluded that learner-instructor interaction was the most required interaction in his summary from several online studies. However, the findings are inconclusive. Some studies indicated that the amount of interaction that learners have with the content is most important to student satisfaction in web-based learning, in comparison with learner-learner interaction and learner-instructor interaction (Chejlyk, 2006; Keeler, 2006).

\section{Internet self-efficacy.}

Expanded from the self-efficacy theory in psychology (Bandura, 1977), researchers in education have indicated that efficacy beliefs positively influence achievement and persistence related to specific instructional tasks (Hodges, 2008; Pintrich \& De Groot, 1990). Internet self-efficacy refers to the belief in one's capability to organize and execute Internet-related actions required to accomplish assigned tasks (Eastin \& LaRose, 2000). There are two reasons to include Internet self-efficacy as a predictor of online student satisfaction. First, online learning relies on Internet delivery through which various types of activities take place such as group discussions, collaborative projects, communication with instructor or classmates, and so on (Roach \& Lemasters, 2006). Technical problems while using the Internet may cause student frustration and dissatisfaction (Choy, McNickle, \& Clayton, 2002). It seems important for online learners to possess high Internet self-efficacy to complete required tasks for an online course delivered through the Internet.

Secondly, Internet self-efficacy, as one of the three self-efficacy constructs in web-based instruction, is less addressed than academic self-efficacy or computer self-efficacy. The impact of Internet self-efficacy on student satisfaction is scarce and inconclusive. For example, Eastin and LaRose (2000) indicated that Internet self-efficacy is positively correlated with expected outcomes including entertainment, social, and informational outcomes. Chu and Chu (2010) found a positive correlation between Internet selfefficacy and satisfaction in their study where adults aged 45 to 87 enrolled in courses on computers. Rodriguez Robles (2006) found Internet self-efficacy is not a significant predictor of student satisfaction in a study involving undergraduates and graduates who attended a web-based distance education course from a university in the United States. 


\section{Self-regulated learning.}

Self-regulation, originally from psychology, was first defined by Bandura (1988). The central ideas underlying self-regulation are motivation and learning strategies that students utilize to achieve their learning goals. The scope of self-regulation has been expanded to studies in education areas (Pintrich, Smith, Garcia, \& McKeachie, 1993). Self-regulated learning refers to the degree to which students metacognitively, motivationally, and behaviorally participate in their own learning (Zimmerman, 1989). Metacognitive processes involve learners' ability to plan, schedule, and evaluate their learning progress. Motivational processes indicate that learners are self-motivated and willing to take responsibility for their successes or failures. Behavior refers to the characteristics of the strategies that students utilize to optimize learning (Zimmerman \& Martinez-Pons, 1986, 1988).

The importance of self-regulation in student performance is evident in traditional faceto-face learning settings (Pintrich \& De Groot, 1990; Zimmerman \& Schunk, 1989). Unlike traditional classroom instruction, online learning is student-centered and much self-directed effort is required for success (Artino, 2007). Although most of the studies have indicated that the ability to self-monitor and self-evaluate at different learning stages is positively related to student performance or achievement, there is very limited research pertaining to the association between self-regulation and student satisfaction. For example, Artino (2007) found motivational components of self-regulation are positively related to student satisfaction from a sample of participants attending military online training in the U.S. Navy. Puzziferro (2008) studied students who took online courses from a liberal arts community college and indicated that meta-cognitive self-regulation is positively correlated with student satisfaction at a significant level.

This study focuses on metacognitive self-regulation because metacognitive processes are considered to be the most critical in self-regulation (Brockett \& Hiemstra, 1991; Corno, 1986; Corno \& Mandinach, 1983; Lee, Kim, \& Grabowski, 2010).

\section{Purpose and Research Questions}

Based upon the literature review, interaction is critical in distance education; however, the literature is inconclusive regarding which type of interaction is most important in predicting student satisfaction in online settings (Bray, Aoki, \& Dlugosh, 2008; Chejlyk, 2006; Keeler, 2006; Rodriguez Robles, 2006). In light of the characteristics of online learning, we assumed that Internet self-efficacy and self-regulation are important in online learning and included them as predictors. Moreover, the scarcity of research leads to ambiguity pertaining to the effect of self-efficacy and self-regulation on student satisfaction (Artino, 2007; Chu \& Chu, 2010; Puzziferro, 2008; Rodriguez Robles, 2006). Hence, the purpose of this study was to investigate the extent to which the potential variables - interaction, Internet self-efficacy, and self-regulation - predict 
student satisfaction in online learning. The influence of student background variables on predictor variables was explored. In addition, this study examined the unique contribution of key predictor variables in explaining the variation of student satisfaction scores.

1. Are the three types of interaction, Internet self-efficacy, and self-regulated learning correlated with student satisfaction?

2. Are the three types of interaction, Internet self-efficacy, and self-regulated learning significant predictors of satisfaction?

3. What are the effects of student background variables (age, gender, marital status, class level, and time spent online per week) on the three types of interaction, Internet self-efficacy, and self-regulated learning?

\section{Method}

\section{Sample}

The sample of this study consisted of undergraduate and graduate students enrolled in summer-session online courses from the College of Education at a western university. The summer-session courses were 12 weeks long. With the permission of and assistance from the instructors who agreed to have their students participate in the study, an online survey link was distributed to 11 online courses (e.g., Adolescence, Cognitive Psychology, Stress Management, Internet Development) from the disciplines of psychology, special education, instructional technology, and physical education. Of the 291 enrolled students from 11 online courses, 111 completed the online survey, a return rate of $38 \%$. The number of respondents in this study fulfilled the requirements of a multiple regression model with 5 independent variables in which at least 75 participants are needed to make confident assumptions about any observed relationships (Stevens, 2002).

There were more female respondents (77\%) than males (23\%). Most respondents were married (64.9\%). Table 1 shows that most respondents were between the ages of 26 and 35 years old. There were only a few students over 46 years old. More than half of the respondents took undergraduate-level courses. Most respondents spent less than 15 hours per week on the online course. 
Table 1

Student Background Information

\begin{tabular}{|c|c|c|}
\hline & Frequency & Percent \\
\hline Gender & & \\
\hline Male & 25 & $23 \%$ \\
\hline Female & 83 & $77 \%$ \\
\hline Marital status & & \\
\hline Married & 69 & $64 \%$ \\
\hline Single & 39 & $36 \%$ \\
\hline Age & & \\
\hline $18-25$ & 37 & $34 \%$ \\
\hline $26-35$ & 54 & $50 \%$ \\
\hline $36-45$ & 13 & $12 \%$ \\
\hline $46-55$ & 4 & $4 \%$ \\
\hline Above 56 & 0 & $0 \%$ \\
\hline Course level & & \\
\hline Undergraduate level & 66 & $61 \%$ \\
\hline $\begin{array}{l}\text { Undergraduate/ graduate } \\
\text { level }\end{array}$ & 18 & $17 \%$ \\
\hline Graduate level & 24 & $22 \%$ \\
\hline Hours spent online per week & & \\
\hline Less than 5 hours & 29 & $27 \%$ \\
\hline 6-10 hours & 41 & $38 \%$ \\
\hline 11-15 hours & 22 & $21 \%$ \\
\hline 16-20 hours & 8 & $7 \%$ \\
\hline Above 20 hours & 8 & $7 \%$ \\
\hline
\end{tabular}




\section{Instrumentation}

The survey included questions on demographics, five predictor variables, and student satisfaction. Demographic questions covered gender, age, marital status, course level, and the hours spent online per week. This study adopted Internet self-efficacy and selfregulation instruments created by prior researchers (see below). Instrument development was involved for interaction and student satisfaction scales.

The Internet self-efficacy scale was developed by Eastin and LaRose (2000) to measure one's confidence in the ability to be successful in performing certain tasks using Internet-based technology. This measurement is a 7-point Likert scale with 8 items that ranged from 1 (very unlikely) to 7 (very likely). This scale was found to be reliable and internally consistent with a Cronbach's coefficient alpha value at .93, based on a population of 171 undergraduate students at a university.

The self-regulated learning scale was adopted from the metacognitive self-regulation subscale in the Motivated Strategies for Learning Questionnaire (MSLQ) developed by Pintrich et al. (1993). The scale is a 7-point Likert scale with 12 items ranging from 1 (not at all true of me) to 7 (very true of me). It assesses the extent to which learners used planning, monitoring, and regulating strategies during the learning process. It is reliable and valid with a coefficient alpha at.79.

The measure of interaction and satisfaction was modified from an existing instrument developed by the authors (2009) in a blended learning environment. It is a 5-point Likert scale ranging from 1 (strongly disagree) to 5 (strongly agree). Three stages were involved in the instrument development process.

- Stage 1: Slight modifications such as wording changes were made to assure the suitability of items given the context of this study was within a fully online learning setting.

- Stage 2: To ensure the content validity of the instrument, a content validity survey was conducted. Six experts, including university professors and professionals with either research expertise or teaching experiences in online learning, were invited to review the questions. Reviewers were asked to rate each item and determine whether the item was adequate for these specific domains on a basis of three choices: essential, useful but not essential, and neither essential nor useful. Content validity ratio (CVR) was calculated based on the ratings from these six experts. The threshold of CVR value to maintain an item for a case of six reviewers is 0.99 (Cohen \& Swerdlik, 2004). Considering the small number of reviewers, we decided to combine "essential" and "useful but not essential" into one option for CVR calculation. Items measuring similar concepts or with a CVR value lower than 0.99 were either removed or combined with other items. Wording changes were made based on the suggestions of reviewers. 
- Stage 3: The slightly revised items and combined items were sent back to the reviewers for a second-round rating to ensure they were adequate and necessary.

After item elimination and revision, there were eight items in the learner-learner interaction subscale, six items in the learner-instructor interaction subscale, and four items in the learner-content interaction subscale (Table 2). The Cronbach's coefficient alpha values, calculated based on the sample of this study, indicated the developed instruments are reliable (Table 2).

Table 2

Reliability Information for Subscales

Scales $\quad$ Number of items $\quad \alpha$

Learner-learner interaction

Learner-instructor interaction

Learner-content interaction

Satisfaction
8

0.99

6

0.88

3

0.92

5

\section{Procedure and Data Analysis}

The researcher contacted instructors about their willingness to include their online students in this survey. Different deliveries were utilized by interested instructors to distribute the survey link, including email, Blackboard announcements, Blackboard discussion threads, or some alternative means. The survey was hosted in SurveyMonkey. To increase the response rate, follow-up emails were sent to instructors as a reminder message.

Data analyses were conducted using SPSS 16.0. Descriptive analyses were conducted to present the student basic information and the average score of predictor variables and student satisfaction. Correlation analysis was performed to understand the relationship between the three types of interactions and student satisfaction. Multiple regression analyses were performed to investigate whether five predictor variables significantly predict student satisfaction. ANOVA was performed to investigate the effect of student background variables on the five predictors. 


\section{Findings}

\section{Descriptive Analyses of Variables}

Table 3 depicts the average scores on the subscales. It seems that the amount of interaction among students is lower than that of interaction between learners and instructor or content. Most of the students had a slightly high level of Internet selfefficacy given that the average score was larger than the mid-point score of 4 . The average score of self-regulation was neutral, implying that students may be able to apply some of the self-regulation skills properly in their learning, but not in a very refined way. Overall, students were moderately satisfied with their learning experiences in an online course.

Table 3

Average Scores on Each Scale

\begin{tabular}{lcccc}
\hline Scales & Range & Midpoint & Mean & SD \\
\hline Learner-learner & $1-5$ & 3 & 2.86 & 1.14 \\
Learner-instructor & $1-5$ & 3 & 3.85 & 0.93 \\
Learner-content & $1-5$ & 3 & 3.93 & 1.01 \\
Internet self-efficacy & $1-7$ & 4 & 5.33 & 1.31 \\
Self-regulated learning & $1-7$ & 4 & 4.04 & 0.81 \\
Satisfaction & $1-5$ & 3 & 4.02 & 0.98 \\
\hline
\end{tabular}

\section{Correlation Analyses}

The Pearson correlation coefficients among the scales are presented in Table 4. The three types of interactions were all positively related to satisfaction. Students' responses on learner-content interaction $(\mathrm{r}=.664, \mathrm{p}<.01)$ and learner-instructor interaction $(\mathrm{r}=$ $.542, \mathrm{p}<.01)$ are relatively highly correlated with student satisfaction in comparison with learner-learner interaction $(r=.246, p<.05)$. It seems that when the interactions of students with their fellow students, instructors, or content increased, the level of 
satisfaction was enhanced. Internet self-efficacy was also positively related to satisfaction $(\mathrm{r}=.437, \mathrm{p}<.01)$. Students who had higher self-efficacy in performing Internet actions tended to be more satisfied with the course. There was no significant relationship between self-regulated learning and satisfaction $(r=-.004, p>.05)$.

Table 4

Correlations between Factors

\begin{tabular}{|c|c|c|c|c|c|c|}
\hline & $\begin{array}{c}\text { Learner- } \\
\text { learner }\end{array}$ & $\begin{array}{l}\text { Learner- } \\
\text { instructor }\end{array}$ & $\begin{array}{r}\text { Learner- } \\
\text { content }\end{array}$ & $\begin{array}{c}\text { Internet self- } \\
\text { efficacy }\end{array}$ & $\begin{array}{c}\text { Self-regulated } \\
\text { learning }\end{array}$ & Satisfaction \\
\hline $\begin{array}{l}\text { Learner- } \\
\text { learner }\end{array}$ & - & $.430 * *$ & $.288^{* *}$ & .057 & .004 & $0.246^{*}$ \\
\hline $\begin{array}{l}\text { Learner- } \\
\text { instructor }\end{array}$ & & - & $.499 * *$ & $.220 *$ & .115 & $0.542^{* *}$ \\
\hline $\begin{array}{l}\text { Learner- } \\
\text { content }\end{array}$ & & & - & $.263 * *$ & .050 & $0.664 * *$ \\
\hline $\begin{array}{l}\text { Internet } \\
\text { self-efficacy }\end{array}$ & & & & - & .063 & $0.437 * *$ \\
\hline $\begin{array}{l}\text { Self- } \\
\text { regulated } \\
\text { learning }\end{array}$ & & & & & - & -0.004 \\
\hline Satisfaction & & & & & & - \\
\hline
\end{tabular}

\section{Regression Analyses}

Multiple regression analysis was performed to see how much the independent variables can predict student satisfaction. The result revealed that the combination of the independent variables significantly predicts student satisfaction $(F(5,102)=26.751, p<$ .001). Approximately $57 \%$ of the variance in student satisfaction was accounted for by the five predictors, including the three types of interaction, Internet self-efficacy, and self-regulated learning. 
Table 5

Multiple Regression of Five Predictors of Student Satisfaction

\begin{tabular}{|c|c|c|c|c|c|c|c|c|c|}
\hline Variables & B & SE B & $\beta$ & $\mathrm{t}$ & $\mathrm{p}$ & Tolerance & VIF & $\begin{array}{l}\text { Semi- } \\
\text { partial }\end{array}$ & $\begin{array}{l}\text { Square } \\
\text { of semi- } \\
\text { partial }\end{array}$ \\
\hline (Constant) & 0.52 & 0.46 & & 1.12 & 0.26 & & & & \\
\hline $\begin{array}{l}\text { Learner- } \\
\text { learner }\end{array}$ & -0.02 & 0.06 & -0.20 & -0.26 & 0.80 & 0.80 & 1.25 & -0.017 & 0.000 \\
\hline $\begin{array}{l}\text { Learner- } \\
\text { instructor }\end{array}$ & 0.28 & 0.09 & 0.27 & 3.28 & $0.00 * *$ & 0.64 & 1.55 & 0.213 & 0.045 \\
\hline $\begin{array}{l}\text { Learner- } \\
\text { content }\end{array}$ & 0.46 & 0.07 & 0.47 & 6.15 & $0.00 * * *$ & 0.72 & 1.39 & 0.401 & 0.161 \\
\hline $\begin{array}{l}\text { Internet self- } \\
\text { efficacy }\end{array}$ & 0.19 & 0.05 & 0.26 & 3.82 & $0.00 * * *$ & 0.92 & 1.09 & 0.249 & 0.062 \\
\hline $\begin{array}{l}\text { Self-regulated } \\
\text { learning }\end{array}$ & -0.09 & 0.08 & -0.07 & -1.12 & 0.26 & 0.98 & 1.02 & -0.073 & 0.005 \\
\hline
\end{tabular}

As shown in Table 5, there was no multicollinearity for the predictors with tolerances larger than .10 and VIFs smaller than 10. Learner-instructor interaction $(\mathrm{t}(102)=3.28$, $\mathrm{p}<.05)$, learner-content interaction $(\mathrm{t}(102)=6.15, \mathrm{p}<.001)$, and Internet self-efficacy $(\mathrm{t}(102)=3.82, \mathrm{p}<.001)$ were significant predictors in explaining student satisfaction. Learner-learner interaction $(\mathrm{t}(102)=-0.26, \mathrm{p}>.05)$ and self-regulated learning $(\mathrm{t}(102)$ $=-1.12, \mathrm{p}>.05$ ) did not significantly contribute to the prediction of student satisfaction.

The squared semipartial correlation (Table 5) informs the uniqueness of a predictor, which is the amount of variance that cannot be explained by other variables entered in the equation. Learner-content interaction explained the largest amount of unique variance (16.1\%) in satisfaction compared to other the four predictors. Internet selfefficacy and learner-instructor interaction followed with $6.2 \%$ and $4.5 \%$ of the unique variance in student satisfaction respectively. 


\section{ANOVA Analyses}

One-way ANOVA analyses were performed to explore the effects of student background variables on the three types of interaction, Internet self-efficacy, and self-regulated learning. Levene's Test of Equality was performed in advance to ensure the assumption of equal variance was met. Age and marital status were found to have no significant influence on any of the predictor variables. Post hoc tests were used to compare all groups of participants with each other.

As indicated in Tables 6 and 7, gender and class level had a significant effect on learnerlearner interaction. Female students $(\mathrm{M}=2.99, \mathrm{SD}=1.07)$ had significantly more learner-learner interaction than male students $(\mathrm{M}=2.44, \mathrm{SD}=1.28), \mathrm{F}(1,106)=4.48, \mathrm{p}$ $<0.05, \eta 2=.04$. Students in undergraduate-level courses $(\mathrm{M}=3.47, \mathrm{SD}=1.10)$ were found to have significantly less interaction with their classmates, as opposed to those in graduate-level courses $(\mathrm{M}=2.65, \mathrm{SD}=1.09), \mathrm{F}(2,105)=4.93, \mathrm{p}<0.01, \eta 2=.08$.

Table 6

One-Way ANOVA of Gender on Predictor Variables

\begin{tabular}{|c|c|c|c|c|c|c|}
\hline & \multicolumn{2}{|c|}{ Male } & \multicolumn{2}{|c|}{ Female } & \multirow[t]{2}{*}{$F(1,106)$} & \multirow[t]{2}{*}{$\eta^{2}$} \\
\hline & & $\mathrm{SD}$ & $\mathrm{M}$ & $\mathrm{SD}$ & & \\
\hline $\begin{array}{l}\text { Learner- } \\
\text { learner }\end{array}$ & 2.44 & 1.28 & 2.99 & 1.07 & $4.48^{*}$ & 0.041 \\
\hline $\begin{array}{l}\text { Learner- } \\
\text { instructor }\end{array}$ & 3.75 & 0.88 & 3.88 & 0.95 & 0.38 & 0.003 \\
\hline $\begin{array}{l}\text { Learner- } \\
\text { content }\end{array}$ & 3.80 & 0.98 & 3.96 & 1.03 & 0.54 & 0.005 \\
\hline $\begin{array}{l}\text { Internet self- } \\
\text { efficacy }\end{array}$ & 5.53 & 1.12 & 5.27 & 1.36 & 0.74 & 0.007 \\
\hline $\begin{array}{l}\text { Self- } \\
\text { regulated } \\
\text { learning }\end{array}$ & 3.97 & 0.77 & 4.06 & 0.82 & 0.24 & 0.002 \\
\hline
\end{tabular}


Table 7

One-Way ANOVA of Class Level on Predictor Variables

\begin{tabular}{lccccc}
\hline & $\begin{array}{c}\text { Undergraduate } \\
\text { M SD }\end{array}$ & $\begin{array}{c}\text { Under/graduate } \\
\text { M SD }\end{array}$ & $\begin{array}{c}\text { Graduate } \\
\text { M SD }\end{array}$ & F(2, 105) & $\eta^{2}$ \\
\hline $\begin{array}{l}\text { Learner- } \\
\text { learner }\end{array}$ & 2.651 .09 & 2.841 .15 & 3.471 .10 & $4.93^{* *}$ & 0.086 \\
$\begin{array}{l}\text { Learner- } \\
\text { instructor }\end{array}$ & 3.790 .94 & 3.751 .11 & 4.100 .72 & 1.08 & 0.020 \\
$\begin{array}{l}\text { Learner- } \\
\text { content }\end{array}$ & 3.91 1.09 & 3.871 .09 & 3.940 .75 & 0.37 & 0.000 \\
$\begin{array}{l}\text { Internet } \\
\text { self-efficacy }\end{array}$ & 5.371 .28 & 5.351 .48 & 5.201 .30 & 0.16 & 0.003 \\
$\begin{array}{l}\text { Self- } \\
\text { regulated } \\
\text { learning }\end{array}$ & 4.050 .80 & 4.150 .99 & 3.930 .67 & 0.39 & 0.007 \\
\hline
\end{tabular}

The number of hours spent online per week was significantly associated with Internet self-efficacy and self-regulated learning; the magnitude of this effect was medium (see Table 8). Students who spent less than 5 hours online each week $(M=5.78, S D=1.11)$ had a significantly higher level of Internet self-efficacy than those who spent more than 20 hours online $(\mathrm{M}=4.27, \mathrm{SD}=1.73), \mathrm{F}(4,103)=2.48, \mathrm{p}<0.05, \eta 2=.08$. Students who spent 11-15 hours online per week for coursework $(\mathrm{M}=4.36, \mathrm{SD}=0.67)$ were significantly more self-regulated as opposed to those who spent less than 5 hours ( $\mathrm{M}=$ $3.70, \mathrm{SD}=0.93), \mathrm{F}(4,103)=2.72, \mathrm{p}<0.05, \eta 2=.09$. 
Table 8

One-Way ANOVA of Hours Spent on Predictor Variables

\begin{tabular}{|c|c|c|c|c|c|c|c|}
\hline & $\begin{array}{l}<5 \mathrm{hrs} \\
\mathrm{M} \mathrm{SD}\end{array}$ & $\begin{array}{c}\text { 6-10 hrs } \\
\text { M SD }\end{array}$ & $\begin{array}{c}11-15 \mathrm{hrs} \\
\mathrm{M} \mathrm{SD}\end{array}$ & $\begin{array}{c}16-20 \mathrm{hrs} \\
\mathrm{MSD}\end{array}$ & $\begin{array}{c}>20 \mathrm{hrs} \\
\mathrm{MSD}\end{array}$ & $F(4,103)$ & $\eta^{2}$ \\
\hline $\begin{array}{l}\text { Learner- } \\
\text { learner }\end{array}$ & 2.391 .19 & 2.901 .10 & 3.181 .03 & 3.021 .24 & 3.331 .04 & 2.16 & $\begin{array}{c}0.07 \\
7\end{array}$ \\
\hline $\begin{array}{l}\text { Learner- } \\
\text { instrutor }\end{array}$ & 3.830 .82 & 3.780 .99 & 4.100 .93 & 3.791 .25 & 3.670 .72 & 0.55 & $\begin{array}{c}0.02 \\
1\end{array}$ \\
\hline $\begin{array}{l}\text { Learner- } \\
\text { content }\end{array}$ & 4.090 .78 & 3.930 .99 & 3.941 .12 & 3.371 .38 & 3.881 .25 & 0.79 & $\begin{array}{c}0.03 \\
0\end{array}$ \\
\hline $\begin{array}{l}\text { Internet } \\
\text { self- } \\
\text { efficacy }\end{array}$ & 5.781 .11 & 5.351 .35 & 5.101 .17 & 5.271 .21 & 4.271 .73 & $2.48^{*}$ & $\begin{array}{c}0.08 \\
8\end{array}$ \\
\hline $\begin{array}{l}\text { Self- } \\
\text { regulated } \\
\text { learning }\end{array}$ & 3.700 .93 & 4.150 .70 & 4.360 .67 & 4.030 .75 & 3.790 .89 & $2.72 *$ & $\begin{array}{c}0.09 \\
6\end{array}$ \\
\hline
\end{tabular}

\section{Discussion}

The purpose of this study was to analyze the effect of important predictor variables on student satisfaction in online settings. The model of this study was built upon Moore's interaction model with the addition of two variables, Internet self-efficacy and selfregulated learning, which were assumed to be important in this study. The results confirmed the importance of interaction (Bray et al., 2008; Chejlyk, 2006; Keeler, 2006; Rodriguez Robles, 2006). All three types of interaction were significantly correlated with student satisfaction. Among the three types of interaction, learner-instructor interaction and learner-content interaction significantly contributed to student satisfaction while learner-learner interaction was a poor predictor of student satisfaction.

Learner-content interaction was the strongest predictor of student satisfaction, which confirms the findings of Chejlyk (2006) and Keeler (2006). Learner-instructor interaction followed as the second strongest predictor that significantly contributed to student satisfaction. This result suggested that the design of online content may be the most important contributor to student satisfaction. Online learners may spend most of 
their time reading and digesting content through thinking, elaboration, and reflection. Organization of content, document layout, and ease of accessing online content may influence learners' interaction with course content. Inclusion of media tools or interactive videos (Anderson, 2003; Havice, Davis, Foxx, \& Havice, 2010) may stimulate learners' motivation to learn and in turn increase student interaction with course content.

To increase learner-content interaction, it is necessary to understand the attributes of technologies that support interaction and instructional design that fits specific learning contexts (Anderson, 2003; Wagner, 1994). Compared to other settings (e.g., synchronous, hybrid), learner-content interaction has greater influence on learning outcomes in asynchronous settings (Bernard, Abrami, Borokhovski, Wade, Tamim, Surkes, \& Bethel, 2009). Inclusion of tasks that involve collaboration and searching online resources may help enhance learners' interaction with content. For instance, problem-based learning would encourage online learners to apply their information search skills to resolve authentic problems, which in turn increases learners' interaction with the content as well as their problem solving skills (An \& Reigeluth, 2008).

Course design would affect learners' interaction with the content and their instructor (Moore \& Kearsley, 2005). Course design with low flexibility leads to reduction of learner-instructor interaction (Eom \& Wen, 2006; Giossos, Koutsouba, Lionarakis, \& Skavantzos, 2009). The more rigid a course, the less autonomy a learner has. A highlystructured course design may be preferred by some online learners as it provides basic course information (e.g., course objectives, teaching strategies, evaluation methods) as well as specified guidelines along with each task or assignment (Lee \& Rha, 2009).

Learner-learner interaction was not a significant predictor for student satisfaction, which is contrary to the studies from J ung et al. (2002) and Rodriguez Robles (2006) where learner-learner interaction was found to be the strongest predictor in web-based learning environments. This finding appears to be reasonable since this study was conducted in fully online environments where students may not have many opportunities to interact with their classmates. In the study of Jung et al. (2002), collaborative activities were designed as part of the online courses, resulting in a significant influence of learner-learner interaction on student satisfaction. The amount of collaborative learning design in online settings seems to be an important factor that leads to the effect of learner-learner interaction on student satisfaction. In terms of social constructivist perspectives, collaborative projects and group assignments enable the processes of conversation, discussion, and negotiation among learners (Woo \& Reeves, 2007). The online courses collected in this study were eight-weeks long and were offered in summer. This type of accelerated online course may decrease instructors' willingness to involve a great amount of group activities given the time constraints.

The significant influence of Internet self-efficacy on student satisfaction was supported in this study, which is contrary to previous research where Internet self-efficacy was not 
found to be a critical factor of student satisfaction (Rodriguez Robles, 2006). Given the results, it may be helpful for institutions to provide appropriate training regarding Internet skills to improve students' Internet self-efficacy before online courses are implemented. Research has shown that students with a higher level of Internet selfefficacy have better information searching skills (Thompson, Meriac, \& Cope, 2002) that may increase their confidence in utilizing the Internet as well as trouble shooting during learning.

Contrary to the study of Puzziferro (2006), self-regulation was neither correlated with nor predictive of student satisfaction. The capability of managing learning pace did not seem to be a critical variable to student satisfaction. However, there were not many studies investigating the effect of self-regulation on student satisfaction in web-based settings. More research may be needed to verify the effect of self-regulation on student satisfaction.

This study also examined the effect of student background variables on three types of interaction, Internet self-efficacy, and self-regulation. Female students were found to engage in more learner-learner interaction than male students. Students in graduatelevel courses had more interaction with their classmates than those in undergraduate courses. Students who registered for advanced courses such as those offered in graduate school may come from similar professional backgrounds and have similar interest in the content area. It may be easier for them to share and exchange ideas with their classmates or brainstorm on content-related topics, which in turn helps the acquisition of content knowledge.

The finding of the association between time spent online and Internet self-efficacy was interesting. It seemed to make sense that students who spent less than 5 hours online had higher Internet self-efficacy than those with more than 20 hours. Students who were more confident in using the Internet for their coursework might have spent less time online; on the contrary, those who were not familiar with the Internet at all might need to spend more time going through the tasks required for the course.

The amount of time spent online per week also significantly influenced students' selfregulation level when comparing the students who spent less than 5 hours with those who spent 11-15 hours. Based on the result, students spending 11-15 hours online per week were more self-regulated than those who spent less than 5 hours. It seemed that 11-15 hours were an adequate amount of time for students to properly manage their learning pace to complete an online course, as opposed to those spending less than 5 hours. Students who spent less than 5 hours online might have rushed through the course content and finished the required tasks without acquiring a deep understanding of the content, given that a more self-regulated person would have better skills in applying appropriate learning methods and managing the learning process to ensure better acquisition of knowledge. 


\section{Limitations and Suggestions for Future Research}

Given the small sample size of this study, future research is recommended to verify and generalize the findings among diverse students. Employing the measurement scales in future studies in alternative contexts may provide additional evidence of the validity of these instruments. In addition, other variables (e.g., class size, course structure, learning style, and so on) that may affect student satisfaction should be included and examined in web-based settings to expand the understanding of online learning (Lee \& Rha, 2009; Zacharis, 2011).

The design of the courses in which students were enrolled was not assessed. This makes it possible that the nature of the course designs led to our finding that learner-learner interaction was not a significant predictor of student satisfaction. Future research should assess the design of online courses and use this as a moderating factor in the prediction of student satisfaction. Such research could shed further light on whether learner-learner interaction is a consistent predictor of student satisfaction.

\section{Conclusions}

This study indicated that the interaction framework with the inclusion of two predictors (i.e., Internet self-efficacy, self-regulation) was valid. Learner-instructor interaction, learner-content interaction, and Internet self-efficacy were significant predictors of student satisfaction in fully online learning settings, while learner-learner interaction and self-regulated learning did not predict student satisfaction. Learner-content interaction was the strongest predictor among those significant predictors of student satisfaction. The importance of interaction in online learning was confirmed. Additionally, gender and class level significantly influenced learner-learner interaction. The effect of time spent per week online was substantially influential for Internet selfefficacy and self-regulation.

The practical implications of this study are that both instructors and course designers should pay attention to content design and organization given that learner-content interaction substantially contributes to student satisfaction. Instructors should pay attention to students and provide feedback to students in a timely fashion or encourage students to ask questions through different mechanisms. Implementing a technology training orientation before online courses start may help increase students' confidence in performing Internet-related tasks required by the course and in turn enhance student satisfaction. Gender and class level seem to be good indicators of the amount of interaction among learners. Instructors are encouraged to design more collaborative activities in undergraduate courses to enhance learner-learner interaction. Time spent online may inform instructors about students' Internet self-efficacy and self-regulation level. 


\section{References}

Allen, M., Bourhis, J., Burrell, N., \& Mabry, E. (2002). Comparing student satisfaction with distance education to traditional classrooms in higher education: A metaanalysis. The American J ournal of Distance Education, 16(2), 83-97.

Allen, I. E., \& Seaman, J . (2008). Staying the course: Online education in the United States, 2008. Retrieved from http://www.sloanc.org/publications/survey/pdf/staying the course.pdf

Allen, I. E., \& Seaman, J . (2010). Class differences: Online education in the United States, 2010. Retrieved from http://sloanconsortium.org/sites/default/files/class_differences.pdf

An, Y. J ., \& Reigeluth, C. M. (2008). Problem-based learning in online environments. Quarterly Review of Distance Education, 9(1), 1- 16.

Anderson, T. (2003). Modes of interaction in distance education: Recent developments and research questions. In M. G. Moore \& W. G. Anderson (Eds.), Handbook of distance education (pp. 129-144). Mahwah, NJ : Erlbaum.

Anderson, T. D., \& Garrison, D. R. (1995). Transactional issues in distance education: The impact of design in audioteleconferencing. The American Journal of Distance Education, 9(2), 27-45.

Artino, A. R. (2007). Online military training: Using a social cognitive view of motivation and self-regulation to understand students' satisfaction, perceived learning, and choice. Quarterly Review of Distance Education, 8(3), 191-202.

Bandura, A. (1977). Self-efficacy: Toward a unifying theory of behavioral change. Psychological Review, 84(2), 191-215.

Bandura, A. (1988). Self-regulation of motivation and action through goal systems. In V. Hamilton, G. H. Bower, \& N. H. Frijda (Eds.), Cognitive perspectives on emotion and motivation (pp. 37-61). Dordrecht, Netherlands: Kluwer Academic.

Battalio, J . (2007). Interaction online: A reevaluation. Quarterly Review of Distance Education, 8(4), 339-352.

Bernard, R. M., Abrami, P. C., Borokhovski, E., Wade, C. A., Tamim, R. M., Surkes, M. A., \& Bethel, E. C. (2009). A meta-analysis of three types of interaction treatments in distance education. Review of Educational Research, 79(3), 12431289. 
Biner, P. M., Bink, M. L., Huffman, M. L., \& Dean, R. S. (1997). The impact of remotesite group size on student satisfaction and relative performance in interactive telecourses. The American J ournal of Distance Education, 11(1), 23-33.

Bolliger, D. U., \& Martindale, T. (2004). Key factors for determining student satisfaction in online courses. International J ournal on E-Learning, 3(1), 61-67.

Bray, E., Aoki, K., \& Dlugosh, L. (2008). Predictors of learning satisfaction in J apanese online distance learners. International Review of Research in Open \& Distance Learning, 9(3), 1-24.

Brockett, R. G., \& Hiemstra, R. (1991). Self-direction in adult learning: Perspectives on theory, research, and practice. New York, NY: Routledge.

Brown, B. W., \& Liedholm, C. E. (2002). Can web courses replace the classroom in principles of microeconomics? American Economics Review, 92(2), 444-448.

Burnett, K. (2001). Interaction and student retention, success and satisfaction in webbased learning. Retrieved from ERIC database. (ED459798)

Chejlyk, S. (2006). The effects of online course format and three components of student perceived interactions on overall course satisfaction. Dissertation Abstracts International, 67(04). (UMI No. 3213421).

Choy, S., McNickle, C., \& Clayton, C. (2002). Learner expectations and experiences: An examination of student views of support in online learning. Leabrook, SA: Australian National Training Authority.

Cohen, R. J., \& Swerdlik, M. E. (2004). Psychological testing and assessment: An introduction to tests and measurements. New York, NY: McGraw-Hill.

Corno, L. (1986). The metacognitive control components of self-regulated learning. Contemporary Educational Psychology, 11(4), 333-346.

Corno, L., \& Mandinach, E. B. (1983). The role of cognitive engagement in classroom learning and motivation. Educational Psychologist, 18(2), 88-108.

Chu, R. J., \& Chu, A. Z. (2010). Multi-level analysis of peer support, Internet selfefficacy and e-learning outcomes: The contextual effects of collectivism and group potency. Computer \&Education, 55, 145-154.

Debourgh, G. (1999). Technology is the tool, teaching is the task: Student satisfaction in distance learning. Paper presented at the Society for Information and Technology \& Teacher Education International Conference, San Antonio, TX.

Eastin, M. S., \& LaRose, R. (2000). Internet self-efficacy and the psychology of the digital divide. Retrieved from http://jcmc.indiana.edu/vol6/ issue1/ eastin.html 
Eom, S. B., \& Wen, H. J. (2006). The determinants of students' perceived leraning outcomes and satisfaction in university online education: An empirical investigation. Decision Sciences Journal of Innovative Education, 4(2), 215235.

Giossos, Y., Koutsouba, M., Lionarakis, A., \& Skavantzos, K. (2009). Reconsidering Moore's transactional distance theory. Retrieved from http:// www.eurodl.org/index.php?article $=374$

Havice, P. A., Davis, T. T., Foxx, K. W., \& Havice, W. L. (2010). The impact of rich media presentations on a distributed learning environment: Engagement and satisfaction of undergraduate students. Quarterly Review of Distance Education, 11(1), 53-58.

Hillman, C. A., Willis, D. J ., \& Gunawardena, C. N. (1995). Learner-interface interaction in distance education: An extension of contemporary models and strategies for practitioners. American J ournal of Distance Education, 8(2), 30-42.

Hodges, C. B. (2008). Self-efficacy in the context of online learning environments: A review of the literature and directions for research. Performance Improvement Quarterly, 20(3/4), 7-25.

Johnson, S. D., Aragon, S. R., Shaik, N., \& Palma-Rivas, N. (2000). Comparative analysis of learner satisfaction and learning outomes in online and face-to-face learning environments. J ournal of Interactive Learning Research, 11(1), 29-49.

J ung, I., Choi, S., Lim, C., \& Leem, J . (2002). Effects of different types of interaction on learning achievement, satisfaction and participation in web-based instruction. Innovations in Education \& Teaching International, 39(2), 153-162.

Kaminski, K., Switzer, J., \& Gloeckner, G. (2009). Workforce readiness: A study of university students' fluency with information technology. Computers \& Education, 53(2), 228-233.

Keeler, L. C. (2006). Student satisfaction and types of interaction in distance education courses. Dissertation Abstracts International, 67(09). (UMI No. 3233345).

Keller, J. M. (1983). Motivational design of instruction. In C. Reigeluth (Ed.), Instructional design theories and models: An overview of their current status (pp. 386-434). Hillsdale, NJ : Erlbaum.

Koseke, G. F., \& Koseke, R. D. (1991). Student burnout as a mediator of the stressoutcome relationship. Research in Higher Education, 32(4), 415-431.

Kuo, Y. C., Eastmond, J. N., Schroder, K. E. E., \& Bennett, L. J. (2009). Student perceptions of interactions and course satisfaction in a blended learning 
environment. Paper presented at the Educational Multimedia, Hypermedia \& Telecommunications World Conference, Hololulu, HI.

Lee, H. J., \& Rha, I. (2009). Influence of structure and interaction on student achievement and satisfaction in web-based distance learning. Educational Technology \& Society, 12(4), 372-382.

Lee, H. W., Kim, K. Y., \& Grabowski, B. L. (2010). Improving self-regulation, learning strategy use, and achievement with metacognitive feedback. Educational Technology Research and Development, 58, 629-648. doi:10.1007/ s11423-0109153-6

Moore, M. G. (1989). Three types of interactions. The American J ournal of Distance Education, 3(2), 1-6.

Moore, M. G., \& Kearsley, G. (1996). Distance education: A systems view. New York, NY: Wadsworth.

Noel-Levitz. (2011). National online learners priorities report. Retrieved from https:// www.noellevitz.com/ upload/Papers and_Research/2011/PSOL_report \%202011.pdf

Northrup, P., Lee, R., \& Burgess, V. (2002). Learner perceptions of online interaction. Paper presented at ED-MEDIA 2002 World Conference on Educational Multimedia, Hypermedia \& Telecommunications, Denver, CO.

Olmstead, J . (2007). Program development, implementation and evaluation: Lessons learned at the University of Wisconsin-Stout. Techniques, 82(6), 22-23.

Parsad, B., \& Lewis, L. (2008). Distance education at degree-granting postsecondary institutions: 2006-07. Retrieved from http://nces.ed.gov/pubs2009/2009044.pdf

Pike, G. R. (1993). The relationship between perceived learning and satisfaction with college: An alternative view. Research in Higher Education, 34(1), 23-40.

Pintrich, P. R., \& De Groot, E. V. (1990). Motivational and self-regulated learning components of classroom academic performance. Journal of Educational Psychology, 82(1), 33-40.

Pintrich, P. R., Smith, D. A., Garcia, T., \& McKeachie, W. J. (1993). Reliability and predictive validity of the motivated strategies for learning questionnaire (MSLQ). Educational and Psychological Measurement, 53(3), 801-813.

Reinhart, J., \& Schneider, P. (2001). Student satisfaction, self-efficacy, and the perception of the two-way audio/video distance learning environment: A 
preliminary examination. Quarterly Review of Distance Education, 2(4), 357365.

Roach, V., \& Lemasters, L. (2006). Satisfaction with online learning: A comparative descriptive study. J ournal of Interactive Online Learning, 5(3), 317-332.

Rodriguez Robles, F. M. (2006). Learner characteristic, interaction and support service variables as predictors of satisfaction in Web-based distance education. Dissertation Abstracts International, 67(07). (UMI No. 3224964).

Puzziferro, M. (2006). Online technologies self-efficacy, self-regulated learning, and experiential variables as predictors of final grade and satisfaction in collegelevel online courses. Dissertation Abstracts International, 66(12). (UMI No. 3199984)

Puzziferro, M. (2008). Online technologies self-efficacy and self-regulated learning as predictors of final grade and satisfaction in college-level online courses. American J ournal of Distance Education, 22(2), 72-89.

Sahin, I. (2007). Predicting student satisfaction in distance education and learning environments. (ERIC Document Reproduction Service No. ED496541).

Stevens, J . P. (2002). Applied multivariate statistics for the social sciences. New J ersey: Lawrence Erlbaum Associates.

Thurmond, V. A. (2003). Examination of interaction variables as predictors of students' satisfaction and willingness to enroll in future web-based courses while controlling for student characteristics. Retrieved from http://www.bookpump.com/dps/pdf-b/1121814b.pdf

Thurmond, V. A., \& Wambach, K. (2004). Understanding interactions in distance education: A review of the literature. International Journal of Instructional Technology and Distance Learning, 1(1), 9-26.

Thompson, L. F., Meriac, J. P., \& Cope, J . G. (2002). Motivating online performance: The influences of goal setting and internet self-efficacy. Social Science Computer Review, 20(2), 149-160.

Wagner, E. D. (1994). In support of a functional definition of interaction. American J ournal of Distance Education, 8(2), 6-29.

Yukselturk, E., \& Yildirim, Z. (2008). Investigation of interaction, online support, course structure and flexibility as the contributing factors to students' satisfaction in an online certificate program. Educational Technology \& Society, 11(4), 51-65. 
Zacharis, N. Z. (2011). The effect of learning style on preference for web-based courses and learning outcomes. British J ournal of Educational Technology, 42(5), 790800 .

Zimmerman, B. J. (1989). A social cognitive view of self-regulated academic learning. J ournal of Educational Psychology, 81(3), 329-339.

Zimmerman, B. J ., \& Martinez-Pons, M. (1986). Development of a structured interview for assessing student use of self-regulated learning strategies. American Educational Research J ournal, 23(4), 614-628.

Zimmerman, B. J., \& Martinez-Pons, M. (1988). Construct validation of a strategy model of student self-regulated learning. J ournal of Educational Psychology, 80(3), 284-290.

Zimmerman, B. J., \& Schunk, D. H. (1989). Self-regulated learning and academic achievement: Theory, research, and practice. New York, NY: Springer-Verlag.

\section{Athabasca University $\mathbf{Z}$}

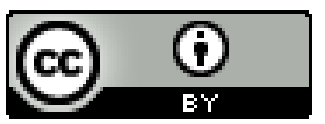

